\title{
Readerly Involvement in the First Chapter of Edna O'Brien's The Country Girls
}

\section{Vanina Jobert-Martini}

\section{(2) OpenEdition \\ 1 Journals}

\section{Electronic version}

URL: http://journals.openedition.org/esa/1468

DOI: $10.4000 /$ esa. 1468

ISSN: 2650-2623

\section{Publisher}

Société de stylistique anglaise

\section{Printed version}

Date of publication: 1 March 2013

Number of pages: 107-117

ISSN: 2116-1747

\section{Electronic reference}

Vanina Jobert-Martini, « Readerly Involvement in the First Chapter of Edna O'Brien's The Country Girls », Études de stylistique anglaise [Online], 4 | 2013, Online since 19 February 2019, connection on 01 May 2019. URL : http://journals.openedition.org/esa/1468 ; DOI : 10.4000/esa.1468 


\title{
READERLY INVOL VEMENT IN THE FIRST CHAPTER OF EDNA O'BRIEN'S
}

\section{THE COUNTRY GIRLS}

\author{
Vanina Jobert-Martini \\ Université Jean Moulin - Lyon 3 \\ ERIBIA GREI EA 2610
}

\begin{abstract}
Résumé : En se fondant sur une étude stylistique du premier chapitre de The Country Girls, l'article s'attache à montrer comment s'établit la relation entre la narratrice et son lecteur. La focalisation interne et les adresses directes au lecteur permettent à celui-ci de se projeter dans le monde rural irlandais des années 50, cadre de l'enfance de la narratrice. Les apports de la stylistique cognitive sont utilisés pour mettre en évidence le jeu des inférences et le caractère prototypique des personnages ou des situations. La dernière partie de l'article s'intéresse aux questions touchant l'évaluation, c'est-à-dire les jugements portés par les personnages, mais aussi par la narratrice et son lecteur, l'ensemble débouchant sur la réception du roman par la critique.
\end{abstract}

Mots-clés: stylistique - narratologie - stylistique cognitive - focalisation - inférence - schèmes - évaluation - réception critique - O' Brien - féminisme - Irlande - réalisme.

\section{Introduction}

Edna O'Brien's first novel The Country Girls was published in 1960 and was followed by The Lonely Girl in 1962, and Girls in their Married Bliss in 1964. The three novels were republished in 1986 as The Country Girls Trilogy and Epilogue. The narrator and focaliser of the first two parts of the trilogy is Kate, but the perspective is reversed in the third part and in the epilogue since Baba, Kate's school-friend becomes the narrator. Byron (2006) quotes O' Brien writing about her choice to have two heroines: 
Realizing that the earlier heroines [of the tradition of Irish writing ] were bawdy and the later ones lyrical I decided to have two, one who would conform to both my own and my country's view of what an Irish woman should be and one who would understand every piece of protocol and religion and hypocrisy that there was. (14)

My own experience as a reader who could not wait to know more about Kate and Baba led me to wonder about the ways and means O'Brien used to achieve stunningly efficient readerly involvement. In order to be able to stick to a close observation of the text, I restricted the scope of the article to the first chapter of the first novel. Probing into the text, I discovered that, predictably, everything concerning reader's involvement was settled from the very beginning. Broaching the subject of the interaction between writer and reader led me to ground the impressions I had from reading in the confrontation between my own experience and the fictional world. For that matter, cognitive stylistics proved a great help without replacing a more traditional text-based approach. I shall first focus on the relationship established between narrator and reader before looking at bottom up and top down processing (see Jeffries \& McIntyre) and moving to the question of evaluation.

\section{Establishing the relationship between narrator and reader}

Edna O'Brien's first novel starts with the following sentence:

I wakened quickly and sat up in bed abruptly. (1)

The awakening of the first-person narrator and main character is concomitant with the entrance of the reader into the fictional world. A link is thus established between narrator and reader from the very beginning. They are placed in the same situation, that of opening their eyes and discovering what is around them. The new day is a new (text-)world, to be explored and deciphered. Character and reader have to make sense of a situation and the puzzled character is very much akin to the reader entering the fictional world:

It is only when I am anxious that I waken easily and for a minute I did not know why my heart was beating faster than usual. Then I remembered. The old reason. He had not come home. (1)

The use of the mental process verb remember gives access to the character's thoughts and is a clear sign of internal focalization. An intimate relationship between narrator and reader is thus quickly established, and the narrator seems to rush things since she does not provide any kind of explanation for who he is, which confuses the reader. The choice of the author may either reveal the narrator's carelessness or technique or even the character's embarrassment. Whatever the case may be, the reader is left to his 
own devices and inferences and is driven to wonder about that male character who occupies the thoughts of the narrator.

There is a sharp contrast between the lack of information about this mysterious man and the wealth of details appearing in the description of the outside world when the blind is let up. Here the reader almost literally sees the world through the eyes of the narrator:

\begin{abstract}
The sun was not yet up, and the lawn was speckled with daisies that were fast asleep. There was dew everywhere. The grass below my window, the hedge around it, the rusty paling wire beyond that, and the big outer field were each touched with a delicate, wandering mist. And the leaves and the trees were bathed in the mist, and the trees looked unreal, like trees in a dream. Around the forget-me-nots that sprouted out of the hedge were haloes of water. Water that glistened like silver. It was quiet, it was perfectly still. There was smoke rising from the blue mountain in the distance. It would be a hot day. (2)
\end{abstract}

This very visual description conjures up a peaceful rural world with a dreamlike quality and reminds the reader of the title The Country Girls. It is followed by several others in the same vein, the repetition building up a sense of familiarity for the reader. The internal focalization prevails throughout the whole chapter as we follow the girl from the moment she wakes up to the moment she leaves the grounds of the house and reaches the road that takes her to school.

In spite of the prevailing internal focalization, there are clear signs that the narrator takes the specific situation of the reader into account, i.e acknowledges the fact that he/she is necessarily a stranger to her familiar world and therefore is in need of information. After mentioning Bull's-Eye, she specifies:

He was our sheep-dog and I named him Bull's-Eye because his eyes were speckled black and white, like canned sweets. (2)

The narrator also provides basic information about Hickey:

He was our workman and I loved him. (3)

Such sentences can be considered as direct addresses to the reader, which tends to increase his involvement in the story. The narrator takes one more step when writing about her mother:

Her sighs would break your heart. (7)

Whether the possessive your is interpreted as part of a general statement or as a possible direct address to the reader, it encourages the reader to get emotionally involved and to share the feelings of the narrator for her beloved mother. 
It is thus possible to gather quite a lot of textual evidence suggesting that the reader is invited to enter into a very close relationship with the narrator, and this is in keeping with the content of the novel i.e. the discussion of private matters. However, the reader's active participation is also required on another level, that of the construction of meaning.

\section{Bottom up and top down processing}

Cognitive linguistics insists on the role played by the reader's psychological activity in the advent of meaning. Lesley Jeffries and Dan McIntyre (2010,127), in Stylistics, make a number of concepts coming from cognitive linguistics accessible and even appealing to even the most literary readers. They define bottom up and top down processes in the following way:

Used in relation to text comprehension, the former [bottom up processes] refers to the practice of inferring meaning from textual cues while the latter term describes the practice of utilising background knowledge to aid understanding.

The elaboration of the fictional world which ultimately exists in the reader's mind depends on these processes, and I shall try to highlight the main characteristics of Edna O'Brien's fictional world as it appears in the first chapter of The Country's Girls.

Leech and Short (1981, 127-8) explain the role of inference as follows:

The mock reality of fiction has its point of overlap with our model of the real world, and indeed it can be argued that readers will assume isomorphism between the two unless given indications to the contrary. The overlap is great in the case of realistic fiction, and smaller in the case of fantasy [...] So from our knowledge of entities and goings-on in the real world, as well as from our knowledge acquired from the text, of the fictional world, we are able to postulate the nature of the fictional world, drawing inferences about matters not directly communicated by the text.

As a matter of fact, The Country Girls can be classified as a realistic novel and the reader is soon aware of a typically rural Irish context. Dublin is mentioned as early as first page as a place from which visitors are likely to come in the Summer time. The reader infers that the place described is situated in the same country as Dublin, otherwise the name of another country would have been mentioned. Belfast is also referred to as a place from which you can drive. Even if place names are a very efficient way of conjuring up a fictional world, writers usually also resort to other means since the aim is not so much to give unequivocal information to the reader but also to play with his imagination. The religious practice of the main character sounds unmistakably Irish and echoes passages form A Portrait of the Artist as a Young Man. Referring to her love for Hickey, the narrator explains: 
To prove it I said it aloud to the Blessed Virgin who was looking at me icily from a guilt frame.

'I love Hickey', I said. She said nothing. It surprised me that she did not talk more often. Once she had spoken to me and what she said was very private. It happened when I got out of bed in the middle of the night to say an aspiration. I got out of bed six or seven times every night as an act of penance. I was afraid of hell. (3)

The reader infers that the girl has received a Catholic education and is a staunch believer. The veracity of this inference is confirmed later on when the girl states her wish to become a nun. This is not the only case in which the text triggers inference and then explicitly confirms that the reader has made a good guess. Poverty can likewise be inferred from the very first page when the narrator explains:

I owned slippers but Mama made me save them for when I was visiting my aunts and cousins $[\ldots](1)$

The reader then learns that hundreds of bills are stuffed behind Doulton plates and that the place has gone to ruin as a result of the father's carelessness. In the same way, we infer that mother and daughter sleep in the same bed when we read:

Getting out, I rested for a moment on the edge of the bed, smoothing the green satin bedspread with my hand. We had forgotten to fold it the previous night, Mama and me. (1)

The confirmation that mother and father do not sleep together is to be found later on:

My father's room was directly opposite the bathroom. (4)

Prompting the reader to make inferences and then giving confirmation is a way of encouraging him to follow the narrator who thus appears reliable.

If inference relies on prior knowledge, it is also the case of top down processing which is to be linked with schemas. Lesley Jeffries and Dan McIntyre (2010, 128-9) give the following definition:

The term schema refers to an element of background knowledge about a particular aspect of the world. We have schemas for people, objects, situations and events.

Since schemas belong in the reader's mind, they may vary a lot, and they cannot really be studied per se. Readers do not all have the same prior knowledge when they start reading a piece of fiction and this may account for various responses to the same novel. Some information cannot be processed without specific prior knowledge. The following sentence is a case in point: 
They called it a lawn because it had been a lawn in the old days when the big house was standing; but the Tans burnt the big house and my father, unlike his forebears, had no pride in land and gradually the place went to ruin. (11)

Such a passage is likely to remain obscure to readers who do not know anything about Irish history, and may have to look up Tans in the encyclopaedia in order to make sense of the sentence. On the contrary, for readers with a fairly good knowledge of Irish history, the passage will evoke specific traumatic episodes of the War of Independence that finally led up to the partition of the island in 1921. Big house may also be interpreted differently by readers, depending on whether they are aware of the Irish specificity or not. Big house may be construed literally as a house that is big or it may be connected with the phrase the big house novel and, in that case, some Irish literature scholars could have in mind a novel which focuses on the world of the Anglo-Irish ascendancy, a world whose territory and boundaries are traditionally conjugated in terms of the demesne and Country Mansion - or Big House - of the Protestant landlord.

The type of knowledge needed to make as much sense as possible of a piece of fiction can help define the kind of implied reader it is addressed to. In the case of The Country Girls, it seems obvious that the implied reader is bound to be well acquainted with contemporary Irish history and possibly with Irish literature. As a matter of fact, the schemas present in the reader's mind have to be triggered by textual elements in order to be activated. The textual cues are called "headers" and they fall into four categories: i) precondition headers, ii) instrumental headers, iii) locale headers and iv) internal conceptualization headers. The most obvious schema activated at the beginning of The Country Girls is that of the mother and daughter relationship. A precondition header, referring to a necessary precondition for the application of a schema ${ }^{1}$, can be found in the sentence quoted previously:

We had forgotten to fold it the previous night, Mama and me. (1)

The first person plural pronoun asserts the existence of the relationship, and the syntactical arrangement of the sentence places the two participants in a rhematic position, highlighting, or foregrounding the importance of the relationship. Locale headers i.e. references to a location where the schema in question can be activated, are numerous since the action is situated in the house inhabited by

1 Jeffries \& McIntyre (2010) specify: "At this point, we should make it clear that while schema is a general term for an element of background knowledge, some writers prefer alternative terms in order to flag up the varied nature of schemas. Minsky (1975), for example uses the term frame to describe knowledge related to visual perception (e.g.background knowledge about different kinds of buildings). Schank and Abelson (1977) introduce the term script, explaining that scripts are composed of schematic information about a complex sequence of events." 
the family and the different rooms and immediate surroundings are described at length. The kitchen deserves a particular mention since it is often associated with mothers in realistic novels, and it is also the room where family life is usually set. A rather sad picture is drawn in the first pages:

Mama was sitting by the range, eating a piece of dry bread. Her blue eyes were small and sore. She hadn't slept. (4)

Internal conceptualization headers, referring to actions or roles from the schema are also very much present in the text, and attract the reader's attention. The mother first appears in the role of the educator teaching her daughter about various aspects of everyday life:

It was lucky that Mama had gone downstairs, as she was always lecturing me on how to let up the blinds properly, gently. (1)

Not surprisingly, she also assumes the role of the nurturer, providing food for her child:

'Get yourself a little piece of cake and biscuits for your lunch,' Mama said. Mama spoilt me, always giving me little dainties. (7)

The mother appears as a carer who protects her daughter against everything that might cause her pain, either physically or psychologically. She insists that her daughter should wear a coat, gloves and a hat, so as not to catch a cold and promises to meet her on the road when she comes back from school.

The text is thus actually swarming with headers likely to activate the mother-daughter good relationship schema. Schemas are not only activated by what we read, they can also be altered -if what we read contradicts our prior knowledge - or confirmed, if what we read corresponds to our previous experience. What is most likely to alter the schema of the mother daughter relationship here is the revelation of the daughter's age. She behaves like a small child, entirely dependent on her mother and yet we learn that she is fourteen and still afraid that her mother might die while she is at school. In spite of their close relationship, mother and daughter grieve and cry because of the father's inability to cope with everyday life and to attend to the needs of the family.

\section{The question of evaluation}

The narrator uses a value language which leaves no doubt about her likes and dislikes. The descriptions of the landscape are extremely positive:

It was crowded with briars and young ferns and stalks of ragwort, and needle-sharp thistles. Under these the ground was speckled with millions of little wild-flowers. Little 
drizzles of blue and white and violet - little white songs spilling out of the earth. How secret and precious and beautiful they were. (11)

The adjectives chosen are both unsophisticated and unmistakably positive, and the musical metaphor gives the passage a poetic touch. In another passage, the narrator expresses her love of nature even more clearly:

I came out to get the lilac. Standing on the stone steps to look across the fields I felt as I always did, that rush of pleasure and freedom when I looked at the various trees and the outer stone buildings set far away from the house, and at the fields very green and very peaceful. (7)

The beautiful nature contrasts with the derelict house which is neither clean, nor pleasant and of which the girl is ashamed when her school-friend, Baba, comes to visit.

The narrator's evaluation extends to people, whom she either loves or loathes. The only person for whom she has ambivalent feelings is Hickey whom she had planned to marry when she was eight years old. She gives all the reasons that made her change her mind:

For one thing, he never washed himself $[\ldots]$ His teeth were green, and last thing at night he did his water in a peach-tin that he kept under his bed. (3)

The humour that shows in this negative evaluation of a likable person is completely absent when the narrator passes judgment on her parents. The father receives an entirely negative evaluation on two different levels, that of facts and that of feelings. He is accused of not doing any work and spending money on drinks instead of caring for the family. The use of free indirect thought indicates that the narrator and her mother are of the same opinion about him:

She was thinking. Thinking where was he? Would he come in an ambulance or a hackney car, hired in Belfast three days ago and not paid for? Would he stumble up the stone steps at the back door waving a bottle of whiskey? Would he shout, struggle, kill her or apologise? Would he fall in the hall door with some drunken fool and say: 'Mother, meet my best friend Harry. I've just given him the thirteen-acre meadow for the loveliest greyhound...' All this had happened to us so many times that it was foolish to expect that my father might come home sober. He had gone, three days before, with sixty pounds in his pocket to pay the rates. (6)

When confronted with this, readers cannot but share the view of the feminine characters and condemn the father for wrong behaviour. This condemnation is based on shared values that do exist between writer and reader, irrespective of differences in age, nationality, social classes, sex etc...

Not surprisingly, the daughter's feelings towards her father are entirely negative. He inspires fear and causes wretchedness. The main character is 
"anxious", the smell of frying bacon "does not cheer her", she is "miserable" and panic-stricken at the idea of his coming back home:

In fear and trembling I set off for school. I might meet him on the way or else he might come home and kill Mama. (9)

The exact opposite of the hated father is the mother:

She was dragged down from heavy work, working to keep the place going, and at night time making lampshades and fire-screens to make the house prettier. (8)

It was only for the few weeks immediately after his drinking that she could relax, before it was time to worry again about the next bout. (11)

Her daughter's love for her is expressed without reservations:

I went over and put my arms round her neck and kissed her. She was the best Mama in the world. I told her so, and she held me very close for a minute, as if she would never let me go. I was everything in the world to her, everything. (5)

It is possible to argue that such extreme feelings and their raw expression are characteristic of young children and that the narrator's phrases are mimetic of the way in which the child used to experience emotion. However, it can also be argued, following Leech and Short (1981) that:

In some novels with a first person hero, there is little need to distinguish the values of the first person character, the narrator, the implied author, and the real author, they all take the same attitude. (276)

In the case of The Country Girls, the dedication To my mother makes us opt for the latter interpretation. The authorial tone is intimate since what prevails is proximity both between narrator and reader and between the author and her subject matter. It is this proximity which induces sympathy for the feminine characters.

However, reader-response was not entirely favourable to Edna O' Brien's novel. Her works were banned by the Irish censorship board and some literary critics were quite harsh with her. The censorship board was aware of the fact that the author's fiction reached far beyond the portrayal of individual characters. The violence of their reaction shows that they considered that the characters depicted were somehow prototypical and that the novelist threatened the established order. They realized that what was at stake was the exposure of the patriarchal society in which the Catholic Church and the state played crucial roles. In Wild Colonial Girl (2006) Coletta and O'Connor remark:

When writing explicitly about Ireland, as she did in her first novels and has resumed to do in her latest work, O'Brien depicts the constricted, hardscrabble life of the villages and farms of the west. Anthropologist Nancy Sheper-Hughes has observed as recently as 
1979 that "although all societies are characterized by sexual asymmetry to some extent, one would be hard put to find a society in which the sexes are as divided into opposing alien camps as they are in any small Irish village of the west." (6)

As for the feminists, they reproached Edna O'Brien with representing women as victims, which was something they wanted to do away with. Still in Wild Colonial Girls Kristine Byron $(2006,22)$ reassesses O’Brien's trilogy and quotes Lynn Pierce:

The recognition also depends on the conflation of the textual with the extratextual - in this case the woman reader's knowledge of the workings of patriarchy, both inside and outside the particular fictional narrative - that enable her to grasp the full connotations of the speaker's 'you'... The textual and the extratextual become indeed a shared territory.

There is no reason why it should not work in the same way for the male reader, provided his ideology does not prevent him from sustaining O'Brien's claims about the Irish patriarchal society.

As is often the case, the main function of the first chapter of The Country Girls is to let the reader into the fictional world. The narrator and main character, who is not named yet and whose gender we guess from the title makes us discover her rural Irish environment and the people she lives with. More originally, we are invited to share her feelings and emotions, which leads us to sympathize with the feminine characters who are clearly the victims of an oppressive patriarchal order. Although we might receive this exposition differently, depending on our age, nationality, cultural background or ideology, it seems difficult to disagree with the narrator. Leech and Short (1981) suggest:

It may be that the assumption of agreement between addresser and addressee is one of the features which distinguishes fictional discourse from other kinds of discourses. It is not that the reader cannot disagree with the values portrayed by the author, but that if he is made conscious of disagreement, this is a sign of the author's failure to carry the reader with him: like suspension of disbelief, suspension of dissent seems to be a sacrifice which the reader is ready to accept in embarking on the adventure of reading a novel. (277) 
Readerly Involvement in the First Chapter of Edna O'Brien's. The Country Girls

\section{Bibliography}

O' BRIEN, Edna, 1960. The Country Girls, London, Phoenix.

JOYCE, James, 2000. A Portrait of the Artist as a Young Man, Oxford, Oxford University Press.

ColettA, Lisa and O'ConnOR, Maureen, 2006. Wild Colonial Girl, Madison, The University of Wisconsin Press.

GreEnwood, Amanda, 2003. Edna O’Brien, Horndon,Tavistock, Devon , Northcote House Publishers Ltd.

LAING, Kathryn, Mooney, Sinead and O'Connor, Maureen, 2006. Edna O'Brien, New Critical Perspectives, Dublin, Carysfort Press.

JefFries, Lesly and McInTYRe, Dan, 2010. Stylistics, Cambridge, Cambridge University Press.

LEECH, Geoffrey and SHORT Michael,1981. Style in Fiction, London, Longman. 